\title{
METODE BIMBINGAN KARIR DALAM \\ MENINGKATKAN KUALITAS SUMBER DAYA MANUSIA PADA ANAK ASUH DI UNIT PELAKSANA TEKNIS DINAS \\ PELAYANAN SOSIAL ASUHAN ANAK (UPTD PSAA) BUDI ASIH BANDAR LAMPUNG
}

\author{
Umi Aisyah ${ }^{1}$ \\ Nariyah Sulistiani ${ }^{2}$ \\ E-mail: umiaeesyah@gmail.com
}

\begin{abstract}
ABSTRAK
Bimbingan karir merupakan bimbingan untuk membantu individu dalam perencanaan, pengembangan, pemahaman diri dan pemecahan berbagai masalah karier. Latar belakang penelitian ini didasari oleh rendahnya kualitas sumber daya manusia (selanjutnya di sebut SDM) yang dimiliki anak asuh ketika awal memasuki UPTD PSAA Budi asih, anak asuh sebelumnya masih kurang wawasan, tidak tau minat bakatnya , tidak dapat merencanakan pilihan karirnya. Masalah ini sangat menarik diteliti karena kualitas SDM sangat mempengaruhi anak asuh dalam meraih kesuksesan karinya. Penelitian ini bertujuan untuk mengetahui bagaimana metode layanan bimbingan karir dalam meningkatkan sumber daya manusia anak asuh di UPTD PSAA Budi Asih Bandar Lampung.

Metode penelitian yang digunakan adalah penelitian kualitatif dalam bentuk penelitain lapangan (field research), yeng bersifat deskriptif. Sumber data dalam penelitian ini ialah 3 orang pembimbing dan 6 anak asuh yang aktif mengikuti kegiatan bimbingan. Adapun teknik pengumpulan data dalam penelitian ini yaitu dangan metode observasi, wawancara, dan dokumentasi.

Berdasarkan hasil penelitian menunjukan bahwa metode dalam pelaksanaan layanan bimbingan karir sebagai peningkatan sumber daya manusia, pembimbing mengunakan metode pelatihan, motivasi (dalam bentuk ceramah), mendatangkan narasumber, dan mengevaluasi kegiatan. Kemudian terkait hasil peningkatan SDM anak asuh, pada awalnya SDM nya masih lemah, namun setelah pelaksanaan layanan bimbingan karir sebagai peningkatan SDM, terdapat perubahan bimbingan karir berhasil meningkatan SDM anak asuh, hal tersebut dilihat dari peningkatan pengetahuan karir yang dimilikinya, dari 6 orang sampel, 3 orang mampu berwirausaha, 1 melanjutkan kuliah dan 2 bekerja sesuai keinginannya.
\end{abstract}

Keywords : Bimbingan Karir, Sumber Daya Manusia, Anak Asuh

\footnotetext{
${ }^{1}$ Dosen Bimbingan dan Konseling Islam UIN Raden Intan Lampung

${ }^{2}$ Mahasiswi Jurusan Bimbingan dan Konseling Islam UIN Raden Intan Lampung
} 


\section{A. Pendahuluan}

Kesejahteraan masyarakat menjadi topik perhatian belakangan ini dan yang paling meningkat yaitu pusat minat ialah pada kesejahteraan anak yang dimaksud adalah bagaimana memenuhi kebutuhan anak agar mendapatkan kehidupan yang layak. Pusat perhatian terhadap kesejahteraan anak merupakan hal yang sangat penting sebab keberadaan anak ialah sesuatu yang berarti dan perlu perhatian yang besar untuk keberlangsungan bangsa. Dimana anak adalah pribadi yang memiliki peranan strategis dalam mengemban tanggung jawab masa depan bangsa dan Negara. ${ }^{3}$ Anak adalah tangung jawab orang tua, namun terkadang orang tua ada yang tidak mampu untuk mengasuh anaknya sendiri yang diakibatkan karena faktor ekonomi maupun sosial sehingga anak tersebut pengasuhannya diserahkan ke lembaga sosial dengan sebutan anak asuh.

Anak asuh merupakan Anak asuh mengacu pada pengertian anak yaitu seseorang yang belum berusia 18 tahun, termasuk anak yang masih dalam kandungan. Jadi, usia 18 tahun ke atas tidak termasuk dalam kriteria anak asuh. Anak Asuh adalah Anak yang diasuh oleh seseorang atau lembaga untuk diberikan bimbingan, pemeliharaan, perawatan, pendidikan, dan kesehatan, karena Orang Tuanya atau salah satu Orang Tuanya tidak mampu menjamin tumbuh kembang Anak secara wajar. ${ }^{4}$ Kriteria anak asuh dalam PP no. 44 tahun 2017 adalah anak terlantar, anak dalam asuhan keluarga yang tidak mampu melaksanakan kewajiban tanggung jawab sebagai orang tua, anak yang memerlukan perlindungan khusus, dan anak yang diasuh oleh Lembaga Asuh Anak.

Unit pelaksanaan Teknis Dinas Pelayanan Sosial Asuhan Anak (UPTD PSAA) Budi Asih yang merupakan bagian dari UPTD Dinas sosial Provinsi Lampung. UPTD ini merupakan salah satu sub dari program kerja dinas daerah provinsi Lampung yang kita kenal dan kebanyakan berada di tengah-tengan

\footnotetext{
${ }^{3}$ Abdullah Nasgih Ulwan, Pendidikan Anak Dalam Islam (Jawa Tengah: Al-Andalus, Cetakan Pertama, 2015), h. iii.

${ }^{4}$ Peraturan Pemerintah Republik Indonesia Nomor 44 Tahun 2017 tentang pelaksanaan pengasuhan Anak Bab I pasal 7
} 
pemukiman warga yang diadakan oleh pemerintah setiap daerah dan dan setiap provinsi di Indonesia. UPTD sebagai turut andil dalam pengembagan dan pembagunan daerah yang berkaitan dengan pembinaan anak asuh seperti yatim, piatu dan yatim piatu.

Dari informasai saat wawancara dengan pembimbing banyak anak asuh yang kurang wawasan atau pengatahuan, masih malas-malasan, tidak tau minat dan baktanya, bahkan tidak bisa menetukan pilihan karirnya artinya anak asuh sangat membutuhkan bimbingan karir. ${ }^{5} \mathrm{Hal}$ ini berarti terdapat masalah sumber daya manusia yaitu lemahnya sumber daya yang dimiliki oleh anak asuh sehingga membutuhkan bimbingan karir sebagai upaya dalam meningkatkanya.

Bimbingan karier merupakan bantuan dalam mempersiapkan diri menghadapi dunia pekerjaan, pemilihan lapangan pekerjaan atau jabatan (profesi) tertentu serta membekali diri agar siap memangku jabatan tersebut dan dalam menyesuikan diri dengan tuntutan-tuntutan dari lapangan pekerjaan yang telah dimasuki. ${ }^{6}$

Layanan bimbingan karir adalah salah satu cara pemberian bantuan dari pembimbing kepada konseli (anak asuh) mengenai masalah karir yang dihadapinya, dengan layanan bimbingan karier ini diharapkan dapat menjadi solusi permasalahan anak asuh serta dapat meningkatkan sumber daya manusia di UPTD PSAA Budi Asih Bandar Lampung

\section{Pengertian sumber daya manusia (SDM)}

Pengertian sumber daya manusia menurut Sonny Sumarsono, Sumber Daya Manusia atau human recources mengandung dua pengertian. Pertama, adalah usaha kerja atau jasa yang dapat diberikan dalam proses produksi. Dalam hal lain sumber daya manusia (SDM) mencerminkan kualitas usaha yang diberikan oleh seseorang dalam waktu tertentu untuk

\footnotetext{
${ }^{5}$ Ibu Maryani pembimbing karir di UPTD PSAA Budi Asih Bandar Lampung, wawancara,22 fabruari 2018

${ }^{6}$ Tohirin, Bimbingan Dan Konseling di Sekolah Dan Madrasah Berbasis Integrasi, (Jakarta : Rawali Pres, 2013) h. 130
} 
menghasilkan barang dan jasa. Pengertian kedua, sumber daya manusia (SDM) menyangkut manusia yang mampu bekerja untuk memberikan jasa atau usaha kerja tersebut.Mampu bekerja berartimampu melakukan kegiatan yang mempunyai kegiatan ekonomis, yaitu bahwa kegiatan tersebut menghasilkan barang atau jasa untuk memenuhi kebutuhan atau masyarakat". ${ }^{7}$

Sementara itu Dalam UNDP (United National Development Programme) yang dikutip oleh Tadjuddin Noer Efendi mendefinisikan pengembangan atau peningkatan sumber daya manusia sebagai berikut: "Pengembangan manusia (sumber daya manusia) adalah proses meningkatkan kemampuan manusia untuk melakukan pilihan-pilihan. Pengertian ini memusatkan perhatian pada pemerataan dalam peningkatan kemampuan manusia (melalui investasi manusia itu sendiri) dan pada pemanfaatan kemampuan itu (melalui penciptaan kerangka keterlibatan manusia untuk mendapatkan dan perluasan kerja)."

Dari pengertian di atas dapat disimpulkan bahwa pengembangan atau peningkatan sumber daya manusia tidak hanya sekedar meningkatkan kemampuan saja, tetapi juga menyangkut pemanfaatan kemampuan manusia, dengan demikian pengembangan sumber daya manusia termasuk di dalamnya meningkatkan partisipasi manusia melalui perluasan kesempatan untuk mendapatkan penghasilan, peluang kerja dan berusaha.

Pengembangan atau peningkatan sumber daya manusia (SDM) adalah upaya untuk meningkatkan kemampuan manusia dengan memberikan kesempatan seluas-luasnya untuk peluang mendpatkan pendidikan, latihan, kesehatan, pekerjaan dan penghasilan. Dalam meningkatakan sumber daya manusia arat kaitanya dengan meningkatkan unsur potensi diri dan pemanfaatan potensi secara optimal.

\footnotetext{
${ }^{7}$ Subagyo, Pengembangan Kualitas Sumber Daya Manusia Pegawai Perusahaan Listrik Negara Rayon Tenggarong Kabupaten Kutai Kartanegara, eJournal Ilmu Pemerintahan, Volume 3, Nomor 2, 2015: 1098-1112 ISSN 0000-000 0 (februari 2018), h. 1101

${ }^{8}$ Tadjuddin Noer Effendi, Sumber Daya Manusia Peluang Kerja Dan Kemiskianan, (Yogyakarta: Tiara Wacana Yogya: 1995), h. 4
} 


\section{Kualitas Sumber Daya Manusia (SDM)}

Dalam meningkankan sumber daya manusia harus mengacu pada Kualitas sumber daya manusia. Kualitas sumber daya manusia sebuah bangsa ditentuakan oleh 3 faktor utama yakni : pendidikan, kesehatan, dan ekonomi. ${ }^{9}$ Oleh karena itu apabila kita menilai kualitas sumber daya manusia (SDM) sebuah bangsa dapat diukur dari tingkat tinggi rendahnya pendidikan, kesehatan, dan ekonomi bangsa tersebut melalui .

a. Pendidikan

Pendidikan adalah suatu upaya untuk mengembangkan potensi manusia. Kemampuan yang dikembangkan dari sumber daya manusia ini mencakup beberapa aspek, aspek utamnya yaitu aspek non-fisik yakni : kemampuan perpikir, penalaran, intelektual, keterampilan, dan sebagainya.

b. Kesehatan

Tingkat kesehatan suatu bangsa dapat dilihat dari angka kematian (mortalitas) dan angka kesakita (morbilitas), melalui berbagai indikator. Indikator yang sering digunakan untuk mengukur derajat kesehatan masyarakat suatu bangsa dan juga sebagai indikator kualitas sumber daya manusia dari aspek kesehatan adalah : angka kematian bayi, angka kematian anak balita, angka kematian ibu karena melahirkan, angaka kematian kasar dan angaka kematian harapan hidup.

c. Ekonomi

Kondisi ekonomi suatu negara dapat menjadi ukuran kualitas sumber daya manusia. Yakni dengan pertumbuhan ekonomi dan dengan indikator pendapatan rata-rata per kapita (income per-capita).

\section{Metode Bimbingan Karir dalam Meningkatkan Kualitas SDM Anak Asuh}

Dalam mengembangkan karirnya anak asuh asuh atau siswa pada dasarnya ada dua teknik pendekatan, teknik pendekatan tersebut yaitu

${ }^{9}$ Soekidjo Notoatmodjo, Pengembangan Sumber Daya Manusia, (Jakarta: Rineka Cipta, 2015), h. 2 
pendekatan kelompok dan pendekatan individual. Sementara bentuk layanan bimbingan karirnya diantaranya yaitu : ceramah diskusi kelompok, karyawisata, pelatihan dan mendatangkan narasumber.

a. Ceramah

Ceramah merupakan bentuk pemberian informasi yang sangat sederhana yang bisa dilakukang siapapun. Ceramah biasanya dilakukan secara lisan dan secara tatap muka. Salah satu contoh nya yaitu bembimbing memberikan motivasi kepada anak asuh atau siswa secara lisan seperti guru yang sedang menyampaikan materi.

Prayitno mengatakan ceramah merupakan metode pemberian informasi yang paling sederhana mudah dan murah, dalam arti bahwa dapat dilakukan oleh hampir setiap petugas disekolah. Disamping itu teknik ini juga tidak memerlukan prosedur biaya yang banyak. ${ }^{10}$

b. Diskusi Kelompok

Diskusi kelompok merupakan salah satu metode dalam bimbingan karir yaitu dengan cara memberi kesempatan kepada siswa untuk memecahkan masalah secara bersma-sama.

c. Karyawisata

Karyawisata bukan hanya berfungsi sebagai rekreasi melainkan sebagai media bimbingan karir, yaitu dengan meninjau onjek-onjek yang menarik serta melihat bagaimana peluang kerja yang ada diluar sehingga dapat dijadikan ladang informasi pemilihan karir.

d. Pelatihan

Pelatihan merupakan metode bimbingan karir yang bertujuan mengembangkan potensi diri. Dalam pelatihan ini pembimbimbing bisa memberikan bimbingan agar peserta dapat memperoleh keterampilan kerja sehingga memiliki SDM yang baik.

${ }^{10}$ Prayitno Dan Erman Amti, Dasar-Dasar Bimbingan Dan Konseling, (Jakarta : Rineka Cipta, 2004), h. 259 
e. Mendatangkan Narasumber

Narasumber adalah istlah yang merujuk kepada sesorang baik yang mewakili pribadi maupun suatu lembaga, yang membrikan tau mengetahui suatu informasi, atu menjadi sumber informasi yang dibutuhkan.Pembimbing mendatangkan narasumber dari luar yang dapat memberikan informasi terkait pilihan karir yang bisa dipilih oleh para siswa atau anak asuh. ${ }^{11}$

\section{B. Metode Penelitian}

\section{Jenis Penelitian}

Jenis penelitian ini adalah penelitian lapangan (field research), yaitu penelitian yang pengumpulan datanya dilakukan di lapangan, yakni menggambarkan dan menafsirkan fokus penelitian yang ada di UPTD PSAA Budi Asih Bandar Lampung sesuai dengan permasalahan yang diteliti yakni bagaimana metode layanan bimbingan karir dalam meningkatkan kualitas Sumber Daya Manusia (SDM) di UPTD PSAA Budi Asih Bandar Lampung

Penelitian ini bersifat kualitatif, dimana suatu penelitian yang ditujukan untuk mendeskripsikan dan menganalisis fenomena, peristiwa, aktivitas sosial, sikap, kepercayaan, persepsi, pemikiran orang secara individual maupun kelompok. ${ }^{12}$ Jadi, dalam penelitian ini data-data yang diperoleh akan disajikan dalam bentuk deskripsi analisis untuk mengungkap metode layanan bimbingan karir dalam meningkatkan kualitas Sumber Daya Manusia (SDM) di UPTD PSAA Budi Asih Bandar Lampung

\section{Sumber Data}

Sumber data penelitian diperoleh dari subjek penelitian, subjek penelitian merupakan orang-orang yang menjadi sumber informasi yang dapat memberikan data sesuai dengan masalah yang diteliti. Subjek penelitian di sini

\footnotetext{
${ }^{11}$ Ibid

${ }^{12}$ Nana Saodih Sukmadinata, Metode Penelitian Pendidikan, (Bandung: Remaja Rosdakarya, 2007), hlm. 60 .
} 
ditentukan berdasarkan pertimbangan tertentu dari pihak peneliti (purposive sampling). ${ }^{13}$ Untuk memperoleh data yang kredibel dan komprehensif, peneliti memandang beberapa orang yang tepat untuk dijadikan informan dalam penelitian ini yaitu sebagai berikut: pembimbing berjumlah 3 orang dan anak asuh berjumlah 6 orang. Kriteria informan berdasarkan cir-ciri tertentu yaitu sebagai berikut :

a. Pembimbing Karir

1) Pegawai UPTD PSAA Budi Asih

2) Memiliki ilmu dalam membimbing

3) Sebagai pembimbing yang melaksakan bimbingan karir.

b. Anak Asuh

1) Anak asuh yang usia pendidikan SLTA.

2) Rajin mengikuti kegiatan bimbingan karir

\section{Teknik Pengumpulan Data}

a. Observasi

Observasi atau pengamatan memungkinkan peneliti melihat dan mengamati sendiri, kemudian mencatat perilaku dan kejadian yang terjadi pada keadaan sebenarnya.

Jenis observasi yang digunakan dalam penelitian ini adalah observasi non partisipan yaitu peneliti tidak terlibat secara aktif dalam kegiatan dan hanya sebagai pengamat independen selama kegiatan penelitian. ${ }^{14}$ Observasi dilakukan untuk melihat bagaimana pelaksanaan metode bimbingan karir dalam meningkatkan SDM anak asuh di UPTD PSAA Budi Asih Bandar Lampung.

b. Wawancara

Wawancara dalam penelitian ini adalah wawancara mendalam yakni pertemuan antara dua orang untuk bertukar informasi dan ide

${ }^{13}$ S. Nasution, Metode Naturalistik Kualitatif, (Bandung: Tarsito, 1992), hlm. 53.

${ }^{14}$ Sugiono, Metode Penelitian Pendidikan pendekatan Kuantitatif, Kualitatif, dan $R \& D$, (Bandung: Alfabeta, 2013), hlm. 204. 
melalui tanya jawab sehingga dapat dikonstruksikan makna dalam suatu topik tertentu. ${ }^{15}$

Metode ini dipilih karena dengan menggunakan wawancara mendalam dapat mengetahui, mengidentifikasi, dan menganalisa pelaksanaan strategi layanan bimbingan dan konseling bagi siswa tunanetra beserta hambatan yang dihadapi selama pelaksanaannya. Wawancara dilakukan untuk mendapatkan data metode apa saja yang digunakan pembimbing dalam memberika bimbingan karir pada anak asuh dan juga mendapatkan data dari anak asuh tentang metode bimbingan karir yang dilaksanakan.

c. Dokumentasi

Metode dokumentasi merupakan suatu teknik dari sumber buku, dokumen, arsip, notulensi, brosur yang ada kaitannya dengan masalah yang hendak diteliti. ${ }^{16}$ Metode ini merupakan alat pengumpul data sekunder untuk mencari data yang berasal dari dokumen yang berguna untuk melengkapi data yang diperoleh dari metode sebelumnya.

\section{Analisis Data}

Teknik anallisa data yang digunakan dalam penelitian ini adalah analisis interaktif model Matwe G. Miles dan Michael Hiberman yang dijelaskan dalam angkah-langkah analisa data sebagai berikut: ${ }^{17}$ Proses menganalisis data dalam penelitian ini dimulai dengan mengumpulkan dan menelaah seluruh data yang diperoleh melalui wawancara, observasi, dan dokumentasi, kemudian mereduksi data (data reduction) yakni proses pemilihan, penyederhanaan, pemusatan perhatian pada hal-hal yang menguatkan data yang diperoleh di lapangan. Setelah itu penyajian data (data display) dengan menyajikan data yang diperoleh dari berbagai sumber kemudian dideskripsikan dalam bentuk uraian atau kalimat-kalimat sesuai

\footnotetext{
${ }^{15}$ Sugiyono, Memahami Penelitian Kualitatif, (Bandung: Alfabeta, 2007), hlm. 72.

${ }^{16}$ Ibid, hlm. 91.

${ }^{17}$ Sugiono, Metode Penelitian Pendidikan, (Bandung: Alfabeta, 2015), hlm. 337-345.
} 
dengan pendekatan kualitatif dalam laporan yang sistematis dan mudah dimengerti. Terakhir verifikasi dan pengambilan kesimpulan (verification dan conclution), proses penarikan kesimpulan didasarkan pada gabungan informasi yang tersusun dalam suatu bentuk pada penyajian data.

\section{Hasil dan Pembahasan}

\section{Analisis Pelaksanaan Metode Bimbingan Karir Dalam Meningkatkan} Kualitas Sumber Daya Manusia Pada Anak Asuh Di Unit Pelaksana Teknis Dinas Pelayanan Sosial Asuhan Anak (UPTD PSAA) Budi Asih

\section{Bandar Lampung}

Sebagaimana dalam observasi dan wawancara yang telah dilakukan oleh penulis, bahwa pelaksanaan layanan bimbingan karir di UPTD PSAA Budi Asih Bandar Lampung sudah berjalan sejak lama, bimbingan karir ini sebagai bentuk layanan bantuan bagi anak asuh yang ada disana.

Berikut wawancara dengan pembimbing Dalam hal ini dingukapkan oleh ibu Tini selaku pembimbing utama dalam pelaksanaan bimbingan karir.

"Kalau bimbingan karir kami lakukan Mbak biasanya satu minggu sekali, pada hari Sabtu biasanya dan itu juga dalam bentuk bimbingan kelompok yang kami lakukan". "Biasanya jam 2 sampai asar, tempatnya di aula, kemudia metodenya dengan pelatihan, pemberian motivasi, mendatangkan narasumber dan evaluasi kegiatan. ${ }^{18}$

Dari pemamparan di atas dapat kita simpulkan waktu dan tempat pelaksanaan bimbingan karir di UPTD PSAA Budi Asih dilaksanakan setiap hari sabtu pukul 14.00 s.d selesai. Kegiatan ini dilakukan secara rutin terjadwal dan dilaksanakan di aula UPTD PSAA Budi Asih dan dilaksanakan secara kelompok.

Dalam pelaksanaan layanan bimbingan karir ini anak asuh dibimbing dengan 3 pembimbing pegawai UPTD PSAA Budi Asih Bandar juni 2018.

${ }^{18}$ Ibu Tini pembimbing karir UPTD PSAA Budi Asih Bandar Lampung, wawancara, 03 
Lampung. Namun para pembimbing juga sering mendatangkan narasumber dari tempat lain dan bergabung dengan beberapa organisasi. Yang biasanya juga memberikan pelatihan dalam rangka bimbingan karir. Dalam pelaksanaan bimbingan karir yang menjadi peserta adalah seluruh anak asuh meskipun dalam penelitian ini difoluskan kepada anak yang usia pendidikannya SLTA.

Berdasarkan hasil wawancara dengan pembimbing di atas Metode yang digunakan dalam memberikan bimbingan karir sebagai peningkatan sumber daya manusia yang dilaksanakan di UPTD PSAA Budi asih yaitu : pelatihan, motivasi, mendatangkan narasumber dan evaluasi kegiatan .

\section{a. Pelatihan}

Pembimbing menggunakan pelatihan ini sebagai metode bimbingan yang paling pokok. Pembimbing mengungkapkan bahwa dengan pelatihan atau praktik langsung anak lebih cepat memahami materi yang disampaikan dan kelihatan hasilnya dalam meningkatkan meningkatkan sumber daya manusia (SDM).

Hal tersebut menjadi alasan mengapa UPTD PSAA Budi Asih lebih mengarahkan mengunakan metode pelatihan. Sangat sesuai dengan teori yang ada, bawasannya pelatihan sangat menunjang keberhasilan dalam meningkatkan sumber daya manusia (SDM). Pelatihan yang diberikan pembimbing mengarahkan kepada aspek kecerdasan motorik sehingga anak asuh mimiliki skill untuk bekal masa depan dan menambah pengetahuan.

Pembimbing juga mengatakan bahwa dengan pelatihan ini, mereka bisa melihat minat dan bakat yang dimiliki dari setiap anak asuh. Sehingga bimbingan yang diberikan bisa diterima dengan baik.

Berikut ini kegiatan pelatihan bimbingan karir dalam meningkatkan kualitas SDM anak asuh yang dilaksanakan di UPTD PSAA Budi Asih dapat dilihat di tabel dibawah ini. 
Tabel 1

Pelaksanaan Layanan Bimbingan Karir Sebagai Peningkatan SDM Dalam Bentuk Pelatihan

\begin{tabular}{|c|c|c|c|c|c|}
\hline No & Tanggal & Uraian Kegiatan & Metode & Pembimbing & Ket. \\
\hline 1 & $03 / 03 / 2018$ & $\begin{array}{l}\text { Keterampilan } \\
\text { buat telur asin }\end{array}$ & Pelatihan & Tini & \\
\hline 2 & $24 / 03 / 2018$ & $\begin{array}{l}\text { Sulam manik- } \\
\text { manik }\end{array}$ & Pelatihan & Maryani & \\
\hline 3 & $31 / 03 / 2018$ & Menjahit & Pelatihan & Maryani & \\
\hline 4 & $14 / 04 / 2018$ & Bordir & Pelatihan & Maryani & \\
\hline 5 & $21 / 04 / 2018$ & $\begin{array}{l}\text { Membuat kue } \\
\text { donat dan bronis }\end{array}$ & Pelatihan & Tini & \\
\hline 6 & $28 / 04 / 2018$ & Kaligrafi & Pelatihan & Hartono & \\
\hline 7 & $05 / 05 / 2018$ & Budi daya lele & Pelatihan & $\begin{array}{c}\text { Yatim } \\
\text { Mandiri }\end{array}$ & \\
\hline 8 & $12 / 05 / 2018$ & Lukisan kaca & Pelatihan & $\begin{array}{l}\text { Yatim } \\
\text { Mandiri }\end{array}$ & \\
\hline 9 & $12 / 05 / 2018$ & Bunga buket & Pelatihan & $\begin{array}{l}\text { Yatim } \\
\text { Mandiri }\end{array}$ & \\
\hline 10 & $19 / 05 / 2018$ & $\begin{array}{l}\text { Pemanfaatan } \\
\text { barang bekas }\end{array}$ & Pelatihan & Tini & \\
\hline 11 & $20 / 05 / 2018$ & $\begin{array}{l}\text { Pelatihan boneka } \\
\text { horta }\end{array}$ & Pelatihan & $\begin{array}{l}\text { Hartono dan } \\
\text { Nariyah } \\
\text { Sulistiani }\end{array}$ & \\
\hline 12 & $26 / 05 / 20$ & Make up artis & Pelatihan & JJE & - \\
\hline 13 & $02 / 06 / 2018$ & $\begin{array}{l}\text { Pengembangan } \\
\text { bakat menari }\end{array}$ & Pelatihan & JJE & $\begin{array}{c}\text { Kerjasa } \\
\text { ma } \\
\text { dengan } \\
\text { organis } \\
\text { asi lain } \\
\text { sebagai } \\
\text { narasu } \\
\text { mber }\end{array}$ \\
\hline
\end{tabular}

Sumber Data : Dokumentasi di UPTD PSAA Budi Asih

Dari tabel di atas dapat diketahui terdapat 13 macam bentuk pelatihan keterampilan yang dilaksanakan dangan pembimbing yang berbeda-beda.

Adapun tahapan-tahapan pelaksanaan bimbingan karir sebagai peningkatan sumber daya manusia (SDM) dalam bentuk pelatihan yaitu sebagai berikut : 
1) Tahap awal

a) Pembukaan : Pembimbing membuka kegiatan bimbingan karir sengan ucapan salam, kemudian menyapa dan menanyakan kabar dan saling berkenalan, menjelaskan maksud dan tujuan.

b) Pembentukan kelompok

Setelah tahapan sebelumnya terlalui pembimbing membentuk kelompok bimbingan karir yang terdiri dari 610 orang.

2) Isi

a) Pembimbing menjelaskan materi pelatihan kepada peserta pelatihan dan memberi kesempatan bertanya kepada peserta mengenai materi yang dismpaikan.

b) Pembimbing mempraktekkan materi yang disampaikan kemudian peserta mulai mengikuti.

c) Masing-masing kelompok bekerjasama dalam memprktikan materi yang diberikan.

d) Menyelesaikan pelatihan

3) Penutup, pembimbing menutup dengan ucapan terimkasih dan salam.

Setelah proses pelatihan selesai, pembimbing tetap memantau dan mengevaluasi perkembangan suber daya manusia anak asuh.

\section{b. Motivasi ( dengan metode ceramah)}

Motivasi adalah dorongan yang timbul pada diri seseorang sadar atau tidak sadar untuk melakukan suatu tindakan dengan tujuan tertentu. Motivasi dalam bentuk ceramah dijadikan sebagai salah salah satu program bimbingan karir di UPTD PSAA Budi Asih, motivasi dengan metode ceramah ini lebih mudah diterapkan oleh pembimbing biasanya dilakukan secara lisan dan secara tatap muka. 
Pembimbing juga mengarahkan pada minat dan bakat yang dimiliki setiap anak. Semangat dan motivasi yang diberikan oleh pembimbing memberikan kekuatan dukungan sosial dan mental kepada anak asuh untuk maju, hal itu diketahui melalui wawancara yang penulis lakukan dangan anak asuh yang menjadi informan.

"kami menganggap pembimbing yang ada disini sebagai orang tua kami mereka selalu memotivasi mendukung dan merawat kami hingga kami berhasil". ${ }^{19}$

Pembimbing yang memberikan bimbingan karir selain pembimbing karir sebagai pegawai tetap, UPTD PSAA Budi Asih bekerjasma dengan organisasi lain, selain itu juga mahasiswa yang datang yang ingin memberikan motivasi juga dipersilahkan. Motivasi materi motivasi yang diberikan yaitu motivasi sekolah lanjutan dan pilihan pekerjaan.

Bimbingan karir dalam bentuk ini bisa dikatakan berhasil, dari 6 oranginforman saat diwawancarai mengatakan ada perubahan pada dirinya setelah mengikuti bimbingan karir, mereka merasa lebih bahagia bisa mengikuti bimbingan karir dan lebih semangat untuk meraih cita-cita serta telah merencanakan karir yang akan dipilihnya.

\section{c. Mendatangkan Narasumber}

Pembimbing UPTD PSAA Budi Asih mendatangkan narasumber untuk mengisi pelatihan dan memotivasi anak dalam merencanakan dan memantapkan pilihan karirnya. Anak asuh menambah pengalaman dan mendapat informasi terkait pilihan karir yang bisa dipilihnya.

Narasumber Yang Pernah Didatangkan Yaitu Yatim Mandiri dan komunitas JJE (Jalan Jalan Edukasi) lampung memberikan pelatihan keterampilan bunga bunga buket, keterampilan kotak tisu dan pembenihan lele. Selain itu juga ada mahasiswa dari UNILA, Malahayati, ITERA dan

\footnotetext{
${ }^{19}$ Luluk Istante Sample Anak Asuh Di UPTD PSAA Budi Asih, Wawancara 20 Mei 2018
} 
juga UIN Raden Intan Lampung yang memberikan bimbingan karir melalui motivasi kepada pendidikan lanjutan.

Selain itu semakin banyak relasi yang ada maka lebih mudah bagi anak asuh mendapatkan informasi seputar karir yang diminatinya.

\section{Evaluasi Kegiatan Bimbingan Karir dalam Meningkatkan}

Setiap kegiatan pasti membutuhkan evaluasi begitu pula dengan bimbimbingan karir yang ada di UPTD PSAA Budi Asih, hal ini bertujuan agar diketahui bagaimana hasil atau perkembangan setiap anak asuh setelah melaksnakan bimbingan karir sebagai peningkatan sumber daya manusia (SDM).

Dari hasil wawancara, pembimbing mengatatakan bahwa setelah pelaksanaan bimbingan karir pembimbing selalu melakukan evaluasi. Evaluasi yang dilakukan yaitu melihat bagaimana peserta didik yang sudah diberi motivasi atau pelatihan perkembangannya. Pembimbing melihat apakah bimbingan yang diberikan diamalkan atau tidak, mampu meningkatakan sumber daya manusia anak asuh atau tidak. ${ }^{20}$

Pembimbing mengatakan bawa ada peningkatan sumber daya manusia pada anak yang mengikuti kegiatan beimbingan karir. Salah satu contohnya adalah setelah dilaksanakan bimbingan karir dalam bentuk pelatihan lukisan kaca, anak asuh mulai menerapkannya bahkan sudah bisa memasarkan hasil karyanya, sudah ada 5 lukisan kaca yang terjual. ${ }^{21}$ Artinya dari evaluasi ini terlihat bahwa ada perkembangan atau peningkatan sumber daya manuisa di UPTD PSAA Budi Asih. Oleh karena itu tujuan dari pelaksanaan bimbimbingan karir sebagai peningkatan sumber daya manusia di UPTD PSAA Budi Asih bisa dikatakan dapat terlaksana dengan baik dan mebuahkan hasil.

\footnotetext{
${ }^{20}$ Ibu Maryani pembimbing karir UPTD PSAA Budi Asih Bandar Lampung, wawancara,03 juni 2018.

${ }^{21}$ Ibu Suhartini dan Bapak Tono pembimbing karir UPTD PSAA Budi Asih Bandar Lampung, wawancara,03 juni 2018.
} 
Selain itu untuk menunjang keberhasilan peningkatan sumber daya manusia anak asuh di UPTD PSAA Budi Asih pembimbing juga memberikan bimbingan langsung untuk belajar berwirausaha (praktek langsung), pelaksanaannya melalui kegitan Panti Expo yang diadakan setiap tahun, kegiatan yang ada didalamnya yaitu bazar hasil karya dari pelatihan yang telah diberikan. Terdapat beberapa kegiatan penunjang prestasi yaitu lomba-lomba yang bertujuan meningkatkan sumber daya manusia sesuai minat dan bakat anak asuh setelah diberikan bimbingan. Selain itu anak sebagian sudah mulai memasarkan secara online kepada teman-temnya melalui sosial media dan dan bayak teman yang memesannya.

Dari empat metode pelaksanaan layanan bimbigan karir di UPTD PSAA Budi Asih berhasil meningkatkan sumber daya manusia anak asuh. Bimbingan karir yang diberikan juga sudah diusahakan semkasimal mungkin oleh pembimbing. Adapun beberapa kekurangan seperti fasilitas atau yang lainya juga sudah disadari oleh pembimbing dan akan segara ditingkatkan.

\section{Daftar Pustaka}

Abdullah Nasgih Ulwan, Pendidikan Anak Dalam Islam, Jawa Tengah: AlAndalus, Cetakan Pertama, 2015.

Peraturan Pemerintah Republik Indonesia Nomor 44 Tahun 2017 tentang pelaksanaan pengasuhan Anak.

Tohirin, Bimbingan Dan Konseling di Sekolah Dan Madrasah Berbasis Integrasi, Jakarta : Rawali Pres, 2013.

Subagyo, Pengembangan Kualitas Sumber Daya Manusia Pegawai Perusahaan Listrik Negara Rayon Tenggarong Kabupaten Kutai Kartanegara, eJournal Ilmu Pemerintahan, Volume 3, Nomor 2, 2015.

Tadjuddin Noer Effendi, Sumber Daya Manusia Peluang Kerja Dan Kemiskianan, Yogyakarta: Tiara Wacana Yogya: 1995.

Soekidjo Notoatmodjo, Pengembangan Sumber Daya Manusia, Jakarta: Rineka Cipta, 2015. 
Prayitno Dan Erman Amti, Dasar-Dasar Bimbingan Dan Konseling, Jakarta : Rineka Cipta, 2004.

Nana Saodih Sukmadinata, Metode Penelitian Pendidikan, Bandung: Remaja Rosdakarya, 2007.

S. Nasution, Metode Naturalistik Kualitatif, Bandung: Tarsito, 1992.

Sugiono, Metode Penelitian Pendidikan pendekatan Kuantitatif, Kualitatif, dan $R \& D$, Bandung: Alfabeta, 2013.

Sugiyono, Memahami Penelitian Kualitatif, Bandung: Alfabeta, 2007. , Metode Penelitian Pendidikan, Bandung: Alfabeta, 2015 